Article

\title{
Self-Organization in Dilute Aqueous Solutions of Thermoresponsive Star-Shaped Six-Arm Poly-2-Alkyl-2-Oxazines and Poly-2-Alkyl-2-Oxazolines
}

\author{
Tatyana Kirila ${ }^{1, *} \mathbb{\infty}$, Anna Smirnova ${ }^{1}$, Vladimir Aseyev ${ }^{2} \mathbb{D}$, Andrey Tenkovtsev ${ }^{1}$, Heikki Tenhu ${ }^{2} \mathbb{D}$ and \\ Alexander Filippov ${ }^{1}$ \\ 1 Institute of Macromolecular Compounds of the Russian Academy of Sciences, Bolshoy pr., 31, \\ 199004 Saint Petersburg, Russia; av.smirnova536@gmail.com (A.S.); avt@hq.macro.ru (A.T.); \\ afil@imc.macro.ru (A.F.) \\ 2 Department of Chemistry, University of Helsinki, 00014 Helsinki, Finland; vladimir.aseyev@helsinki.fi (V.A.); \\ heikki.tenhu@helsinki.fi (H.T.) \\ * Correspondence: tatyana_pyx@mail.ru; Tel.: +7-812-328-4102
}

check for updates

Citation: Kirila, T.; Smirnova, A.; Aseyev, V.; Tenkovtsev, A.; Tenhu, H.; Filippov, A. Self-Organization in Dilute Aqueous Solutions of

Thermoresponsive Star-Shaped Six-Arm Poly-2-Alkyl-2-Oxazines and Poly-2-Alkyl-2-Oxazolines. Polymers 2021, 13, 1429. https://doi.org/ $10.3390 /$ polym 13091429

Academic Editors: Alexey Bubnov and Mattia Sponchioni

Received: 30 March 2021

Accepted: 26 April 2021

Published: 29 April 2021

Publisher's Note: MDPI stays neutra with regard to jurisdictional claims in published maps and institutional affiliations.

Copyright: (c) 2021 by the authors. Licensee MDPI, Basel, Switzerland. This article is an open access article distributed under the terms and conditions of the Creative Commons Attribution (CC BY) license (https:/ / creativecommons.org/licenses/by/ $4.0 /)$.

\begin{abstract}
The behavior of star-shaped six-arm poly-2-alkyl-2-oxazines and poly-2-alkyl-2-oxazolines in aqueous solutions on heating was studied by light scattering, turbidimetry and microcalorimetry. The core of stars was hexaaza $\left[2_{6}\right]$ orthoparacyclophane and the arms were poly-2-ethyl-2-oxazine, poly-2-isopropyl-2-oxazine, poly-2-ethyl-2-oxazoline, and poly-2-isopropyl-2-oxazoline. The arm structure affects the properties of polymers already at low temperatures. Molecules and aggregates were present in solutions of poly-2-alkyl-2-oxazines, while aggregates of two types were observed in the case of poly-2-alkyl-2-oxazolines. On heating below the phase separation temperature, the characteristics of the investigated solutions did not depend practically on temperature. An increase in the dehydration degree of poly-2-alkyl-2-oxazines and poly-2-alkyl-2-oxazolines led to the formation of intermolecular hydrogen bonds, and aggregation was the dominant process near the phase separation temperature. It was shown that the characteristics of the phase transition in solutions of the studied polymer stars are determined primarily by the arm structure, while the influence of the molar mass is not so significant. In comparison with literature data, the role of the hydrophobic core structure in the formation of the properties of star-shaped polymers was analyzed.
\end{abstract}

Keywords: thermoresponsive star-shaped polymers; poly-2-alkyl-2-oxazines and poly-2-alkyl-2oxazolines; aqueous solutions; light scattering; turbidimetry; microcalorimetry; phase separation; aggregation

\section{Introduction}

Thermoresponsive pseudo-polypeptoids have attracted great interest of researchers in recent years due to the wide potential of their application, for example, in medicine as nanocontainers for targeted delivery of drugs [1-3]. For them, the synthesis conditions were determined, allowing obtaining polymers with a given structure and molar mass characteristics. The linear pseudo-polypeptoids have been studied in sufficient detail, and influence of their chemical structure and molar mass on the physico-chemical properties, in particular, on self-organization of macromolecules and thermoresponsiveness in aqueous solutions was established [4-10].

One of the most well-studied classes of thermosensitive pseudo-polypeptoids is poly2-alkyl-2-oxazolines (PAlOx). They demonstrate LSCT behavior in water-salt solutions, and the phase separation temperature depends on the length of the side radical and can range from practically zero to $100{ }^{\circ} \mathrm{C}$ [11]. Due to their biocompatibility and stability in biological media, they are widely used in medical applications and biotechnology [2,12,13]. In particular, complexes of linear PAlOx with low molecular weight compounds were 
obtained, which are used as delivery systems for drugs, DNA, as well as materials for creating biocompatible composite structures [14].

Poly-2-alkyl-2-oxazines (PAlOz) are homologs of poly-2-alkyl-2-oxazolines. The presence of an additional methylene group in the monomer unit makes them more hydrophobic than PAlOx [15-17]. In contrast to poly-2-alkyl-2-oxazines, $\mathrm{PAlOz}$ have been studied in much less detail [18], although the synthesis of these polymers was described at about the same time [19]. This situation is associated with the difficulties of synthesis of PAlOz, namely, the reaction for the preparation of $\mathrm{PAlOz}$ is characterized by low polymerization rate constants and a high chain transfer rate. This makes it difficult to obtain the high molar mass samples $[20,21]$. It should be noted that PAlOz has a number of advantages over PAlOx. For PAlOz, no irreversible crystallization in water was found upon prolonged heating above the phase separation temperature, which is characteristic of poly-2-isopropyl-2-oxazoline [22,23]. It seems even more significant that for PAlOz good binding of water-insoluble medicinal compounds was found [24].

In connection with biomedical applications, special attention is paid to the study of pseudo-polypeptoids with complex architecture, in particular, polymer stars. For starshaped PAlOx, the effect of the structure of arms, their number and length, as well as the solvent composition on the thermosensitivity was analyzed [25-27]. The possibilities of using star-shaped polymers as carriers of drugs to a great extent depend on the structure and properties of the branching center. For example, calix $[n]$ arenes and resorcinarenes are prone to self-organization and the formation of nanoscale assemblies [28,29]; therefore, their use as the core of star molecules significantly increases the binding efficiency of low-molecular-weight drugs.

Star-shaped polymers based on aza $\left[1_{n}\right]$ cyclophans have practically not been described so far, although the aza [1 $\mathrm{n}$ ] cyclophans have been known of since 1963 [30]. Hexaase $\left[2_{6}\right]$ metacyclophane and hexaase $\left[2_{6}\right]$ orthoparacyclophane can be obtained in high yield by reduction in the corresponding macrocyclic Schiff bases [31].

In our previous work [25], for the first time, star-shaped six-arm pseudo-polypeptoids with hexaaza $\left[2_{6}\right]$ orthoparacyclophane core were synthesized using cationic ring-opening polymerization. Four polymers were obtained, namely, star-shaped poly-2-ethyl-2-oxazine (CPh6-PEtOz), poly-2-isopropyl-2-oxazine (CPh6-PiPrOz), poly-2-ethyl-2-oxazoline (CPh6$\mathrm{PEtOx}$ ), and poly-2-isopropyl-2-oxazoline (CPh6-PiPrOx) (Figure 1). Conformational behavior of star-shaped poly-2-alkyl-2-oxazines (CPh6-PAlOz) and poly-2-alkyl-2-oxazolines (CPh6-PAlOx) were investigated by the methods of molecular hydrodynamics and optics in molecular dispersed solutions. It was established that conformation characteristics of CPh6-PAlOz and CPh6-PAlOx depended on arm length, while the chemical structure weakly affected the solution behavior of the star-shaped pseudo-polypeptoids. The starshaped CPh6-PAlOz and CPh6-PAlOx are characterized by higher intramolecular density in comparison with their linear analogs. Taking into account the prospects of practical application, the influence of salt on the self-organization in $\mathrm{CPh} 6-\mathrm{PAlOz}$ and $\mathrm{CPh} 6-\mathrm{PAlOx}$ solutions was studied [32]. $\mathrm{NaCl}$ and $\mathrm{N}$-methylpyridinium p-toluenesulfonate (N-PTS) were used as salts. It was found that the effect of salt on the thermosensitivity of the discussed stars depends on the structure of the salt and polymer and on the salt content in the solution. For $\mathrm{NaCl}$ solutions, the phase separation temperature monotonically decreased with the growth of salt concentration. In N-PTS solutions, the dependence of the phase separation temperature on the salt concentration was non-monotonic with minimum at salt concentration corresponding to one salt molecule per one arm of a polymer star. 


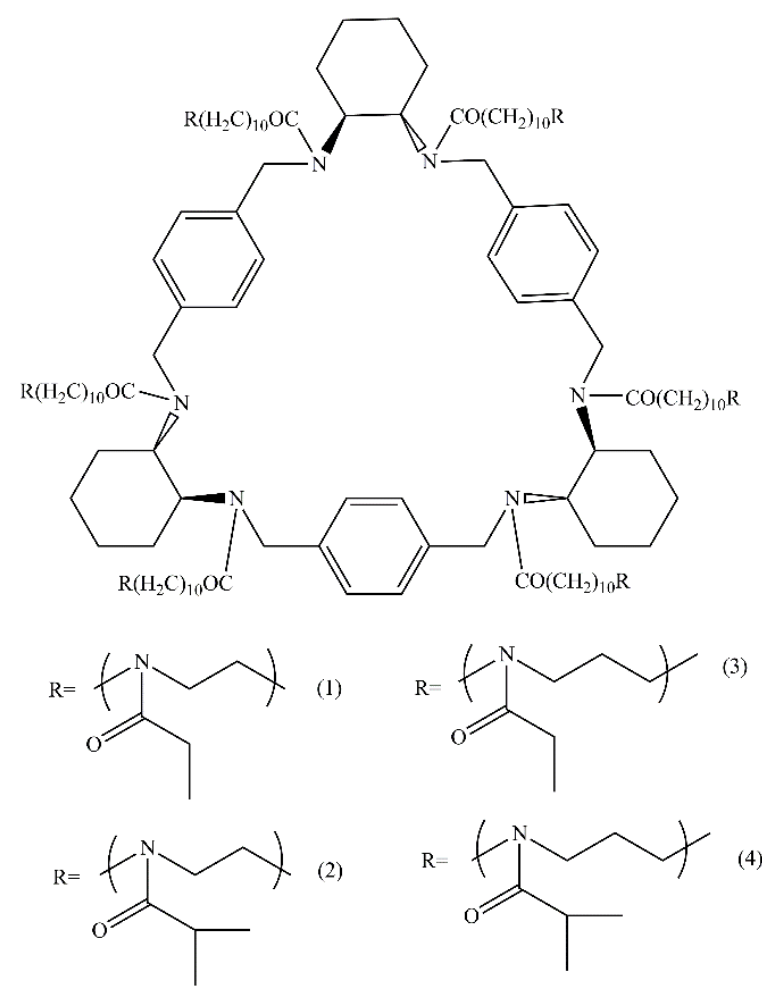

Figure 1. Structure of star-shaped CPh6-PEtOx (1), CPh6-PiPrOx (2), CPh6-PEtOz (3), and CPh6$\mathrm{PiPrOz}(4)$.

The aim of the present work is to investigate the effect of the arm structure and, accordingly, the hydrophobicity of the molecules on self-organization and aggregation in water solutions of thermoresponsive star-shaped CPh6-PAlOz and CPh6-PAlOx on heating.

\section{Materials and Methods}

\subsection{Polymer Star Synthesis}

The synthesis of star-shaped six-arm thermosensitive poly-2-alkyl-2-oxazolines and poly-2-alkyl-2-oxazines with a hexaase $\left[2_{6}\right]$ orthoparacyclophane core has been described in detail earlier [25]. The molar mass characteristics of the samples were determined in chloroform. The molar masses (MM) of CPh6-PEtOz and CPh6-PiPrOz are higher than MM of CPh6-PEtOx and CPh6-PiPrOx (Table 1). Accordingly, the molar fraction $\omega$ of hydrophobic groups in CPh6-PEtOz (7.2 mol \%) and CPh6-PiPrOz ( $8.3 \mathrm{~mol} \%)$ is almost one and a half times lower than in CPh6-PEtOx (11.0 mol \%) and CPh6-PiPrOx (11.8 mol \%). The values of dispersity factor $Ð=M_{\mathrm{W}} / M_{\mathrm{n}}$ of investigated samples were calculated using GPC curves which were obtained in [25]. However, it should be taken into account that linear standards were used in the GPC analysis. Accordingly, the obtained $Đ$ values should be considered as an estimate of the polydispersion.

Table 1. Molar masses and average values of hydrodynamic radii of scattering object in aqueous solutions of investigated stars-shaped CPh6-PAlOx and CPh6-PAlOz.

\begin{tabular}{|c|c|c|c|c|c|c|c|c|c|c|}
\hline Polymer & $M_{\mathrm{sD}}{ }^{(1)} \mathrm{g} \mathrm{mol}^{-1}$ & $\boxplus^{(2)}$ & $R_{\mathrm{h}-\mathrm{D}}{ }^{(1)} \mathrm{nm}$ & $<R_{\mathrm{f}}>, \mathrm{nm}$ & $<R_{\mathrm{m}}>, \mathrm{nm}$ & $<R_{\mathrm{s}}>, \mathrm{nm}$ & $\left.<S_{\mathrm{f}}\right\rangle$ & $<S_{\mathrm{m}}>$ & $<S_{\mathrm{s}}>$ & $C_{\mathrm{s}}$ \\
\hline CPh6-PEtOz & 23,000 & 1.27 & 3.5 & $3.9 \pm 0.3$ & - & $89 \pm 8$ & 0.09 & - & 0.91 & 0.07 \\
\hline CPh6-PiPrOz & 20,000 & 1.24 & 3.3 & $4.1 \pm 0.3$ & - & $89 \pm 9$ & 0.10 & - & 0.92 & 0.07 \\
\hline CPh6-PEtOx & 15,000 & 1.29 & 3.0 & - & $6.3 \pm 0.7$ & $84 \pm 7$ & - & 0.35 & 0.65 & 0.06 \\
\hline CPh6-PiPrOx & 14,000 & 1.19 & 2.6 & - & $15 \pm 1$ & $86 \pm 12$ & - & 0.84 & 0.16 & 0.08 \\
\hline
\end{tabular}

(1) the values of $M_{\mathrm{SD}}$ and $R_{\mathrm{h}-\mathrm{D}}$ were obtained in [25]. ${ }^{(2)}$ the values of $\bigoplus$ were calculated using GPC curves which were obtained in [25]. 


\subsection{Solution Investigation}

The thermosensitive behavior of star-shaped pseudo-polypeptoids was studied by light scattering and turbidimetry on a PhotoCor Complex (Photocor Instruments Inc., Moscow, Russia) setup with a diode laser and a sensor for measuring optical transmission. Wavelength is $\lambda=659.1 \mathrm{~nm}$. The studies were carried out in the temperature range $T$ from 5 to $75^{\circ} \mathrm{C}$. The value of $T$ was changed discretely with a step from 0.5 to $5{ }^{\circ} \mathrm{C}$ and was regulated with an accuracy of $0.1^{\circ} \mathrm{C}$.

The measurement procedure was described in detail [33]. For all solutions, the values of the scattered light intensity $I$, optical transmission $I^{*}$, hydrodynamic radii $R_{\mathrm{h}}$ of scattering objects and their $S_{i}$ contribution to the total light scattering were determined. The $S_{\mathrm{i}}$ values were obtained from the area of the corresponding peak in the intensity distribution $I$ over $R_{\mathrm{h}}$.

After the given temperature was established, only the dependences of the light scattering intensity $I$ and optical transmission $I^{*}$ on time $t$ were recorded. These measurements were carried out at a scattering angle of $90^{\circ}$. When the changes in $I$ were no more than $1 \%$ over the time required for the accumulation and processing of the autocorrelation function, the distribution of $I$ over the hydrodynamic radii $R_{\mathrm{h}}$ was obtained, and the angular dependences of the values of $I, R_{\mathrm{h}}$, and $S_{\mathrm{i}}$ were analyzed in the range of light scattering angles from $45^{\circ}$ to $135^{\circ}$ in order to prove the diffusion nature of the modes, as well as to obtain extrapolated values of $R_{\mathrm{h}}$ (Figure 2). In all experiments, the time $t_{\mathrm{eq}}$ required to achieve time constant values of $I, R_{\mathrm{h}}$, and $S_{\mathrm{i}}$ was recorded. Since the phase separation temperatures for CPh6-PEtOx and CPh6-PEtOz at $c<0.01 \mathrm{~g} \mathrm{~cm}^{-3}$ had values above $75^{\circ} \mathrm{C}$, measurements for these solutions were carried out on a Zetasizer Nano ZS (Malvern Instruments Limited, Worcestershire, UK) particle analyzer in the temperature range from 15 to $100{ }^{\circ} \mathrm{C}$.
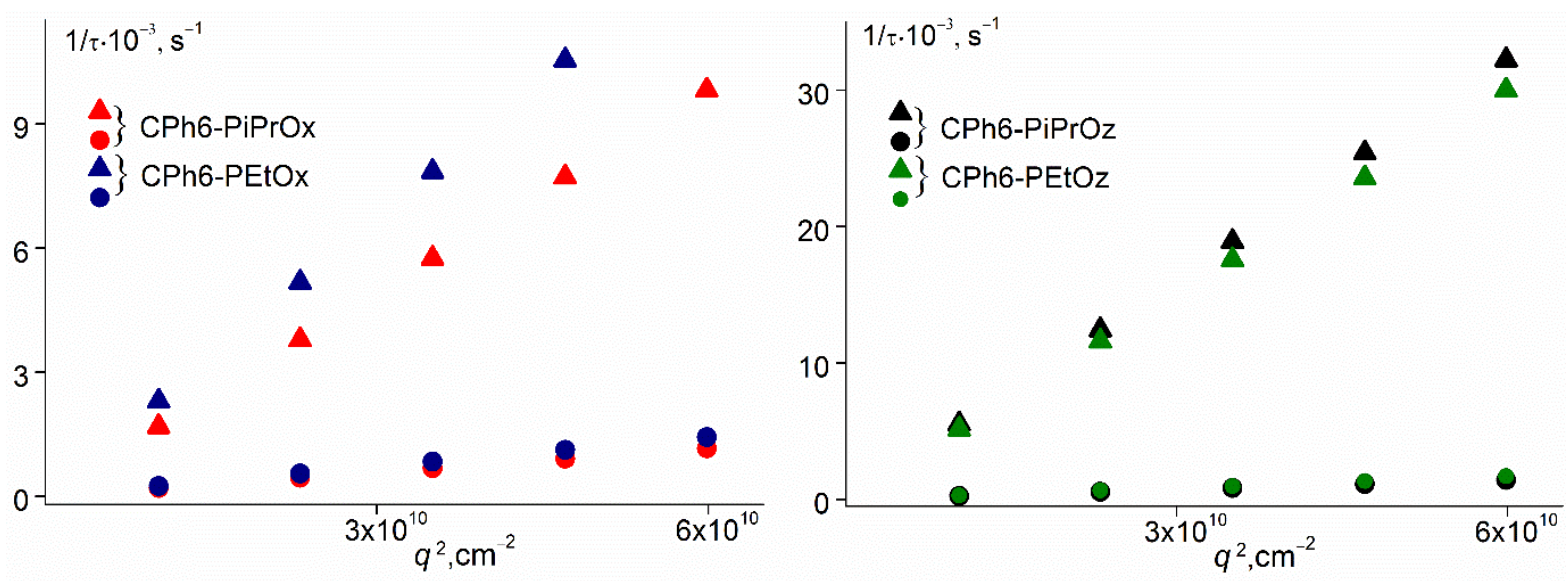

Figure 2. Relaxation time $1 / \tau$ on squared wave vector $q^{2}$ for CPh6-PAlOz and CPh6-PAlOx at $21^{\circ} \mathrm{C}$.

The polymer concentrations varied from 0.0002 to $0.015 \mathrm{~g} \mathrm{~cm}^{-3}$ for CPh6-PiPrOx and CPh6-PiPrOz and from 0.005 to $0.025 \mathrm{~g} \cdot \mathrm{cm}^{-3}$ for CPh6-PEtOx and CPh6-PEtOz. The solutions were filtered into dust-free vials using Millipore filters with hydrophilic PTFE membrane and pore size of $0.45 \mu \mathrm{m}$ (Merck KGaA, Darmstadt, Germany).

Microcalorimetric studies of aqueous solutions of star-shaped $\mathrm{CPh} 6-\mathrm{PAlOz}$ and $\mathrm{CPh} 6-$ PAlOx were carried out on a MicroCal PEAQ-DSC microcalorimeter (Malvern Instruments Limited, Worcestershire, UK) with a capillary cell with a volume of $0.507 \mathrm{~mL}$ at a heating rate of $1{ }^{\circ} \mathrm{C} / \mathrm{min}$ and a pressure of $50 \mathrm{kPa}$. The temperature range of measurements was chosen depending on the characteristics of the polymer (from 5 to $60^{\circ} \mathrm{C}$ for $\mathrm{CPh} 6-\mathrm{PiPrOz}$ and from 15 to $100{ }^{\circ} \mathrm{C}$ for $\mathrm{CPh} 6-\mathrm{PiPrOx}, \mathrm{CPh} 6-\mathrm{PEtOx}$, and CPh6-PEtOz). The solution concentrations varied from 0.001 to $0.015 \mathrm{~g} \mathrm{~cm}^{-3}$ for CPh6-PiPrOx and $\mathrm{CPh} 6-\mathrm{PiPrOz}$, and from 0.005 to $0.025 \mathrm{~g} \mathrm{~cm}^{-3}$ for CPh6-PEtOx and CPh6-PEtOz. The phase transition heat $\Delta H$ was calculated using the OriginLab taking into account the polymer concentration. 


\section{Results and Discussion}

3.1. Behavior of Star-Shaped Six-Arm Pseudo-Polypeptoids in Aqueous Solutions at Low Temperatures

At low temperatures, the aqueous solutions of the studied polymer stars were not molecularly dispersed; there were two types of scattering objects at all concentrations (Figure 3). However, the behavior of CPh6-PAlOz and CPh6-PAlOx was markedly different. In the case of CPh6-PEtOz and CPh6-PiPrOz, the radii $R_{\mathrm{f}}$ of the particles responsible for the fast mode (Table 1 ) were close to the hydrodynamic radii $R_{\mathrm{h}-\mathrm{D}}$ of the macromolecules of the stars under consideration, determined in an organic solvent in which there were no associative phenomena [25]. Therefore, particles with radius $R_{\mathrm{f}}$ could be considered as individual star-shaped macromolecules. Taking into account the hydrophobicity of the $\mathrm{CPh} 6$ core and the hydrophilicity of the $\mathrm{PEtOz}$ arms, it can be assumed that the structure of $\mathrm{CPh} 6-\mathrm{PAlOz}$ molecules in aqueous solutions is similar to that of unimolecular micelles of the core-shell type [34-37]. For both PAlOz stars, the $R_{\mathrm{f}}$ values did not depend on the polymer concentration (Figure 4).
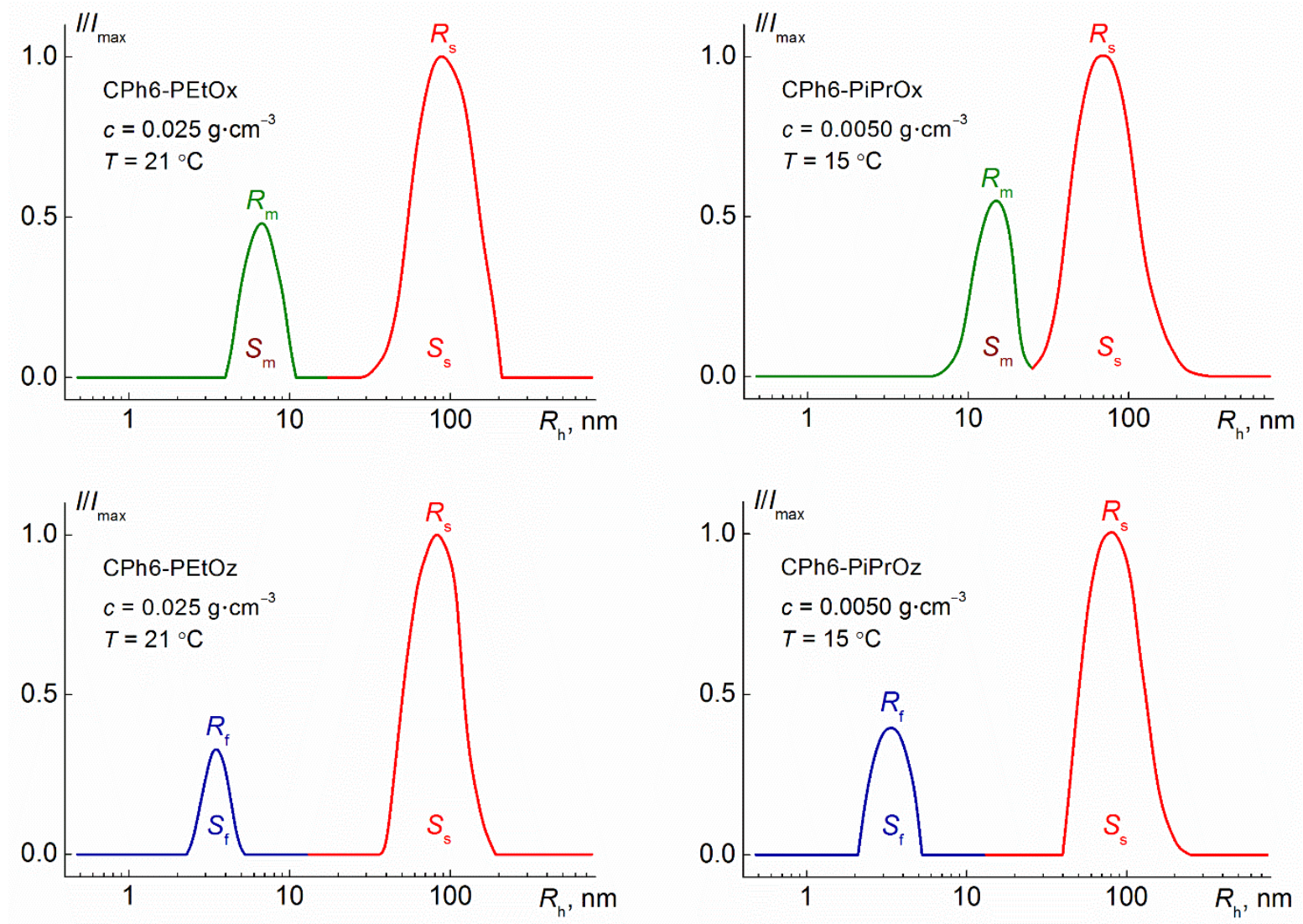

Figure 3. The distributions of light scattering intensity over hydrodynamic radii of scattering species for solutions of starshaped pseudo-polypeptoids. $R_{\mathrm{f}}, R_{\mathrm{m}}$, and $R \mathrm{~s}$, are the hydrodynamic radii of macromolecules (fast mode), small aggregates (middle mode) and large aggregates (slow mode), respectively. $S_{\mathrm{f}}, S_{\mathrm{m}}$, and $S_{\mathrm{s}}$ are contributions of the corresponding modes to the total light scattering.

In exactly the same way, no concentration dependence was found for the species responsible for the faster mode in CPh6-PEtOx and CPh6-PiPrOx solutions. However, the radii $R_{\mathrm{m}}$ of these particles differed markedly from $R_{\mathrm{h}-\mathrm{D}}$ for CPh6-PAlOx. For CPh6PEtOx, the concentration-averaged value $\left\langle R_{\mathrm{m}}>=(6.3 \pm 0.7) \mathrm{nm}\right.$ is 2.1 times higher than $R_{\mathrm{h}-\mathrm{D}}=3.0 \mathrm{~nm}$. For CPh6-PiPrOx, the discussed parameters differed more strongly: $<R_{\mathrm{m}}>=(15 \pm 1) \mathrm{nm}$ and $R_{\mathrm{h}-\mathrm{D}}=2.6 \mathrm{~nm}$. Therefore, the species under discussion are supramolecular structures. Similar aggregates, which are usually called micelle-like structures, have been repeatedly observed for stimulus-sensitive polymers [6,35,38-42], includ- 
ing the star-shaped PAlOx and PAlOz [43-46]. The formation of these supramolecular structures in solutions of the studied CPh6-PAlOx is mainly caused by interaction of hydrophobic $\mathrm{CPh} 6$ core. This explains the difference in the behavior of $\mathrm{CPh} 6-\mathrm{PAlOx}$ and CPh6-PAlOz. In the CPh6-PEtOz and CPh6-PiPrOz molecules, the hexaaza $\left[2_{6}\right]$ orthoparacyclophane core is well shielded from water molecules by the hydrophilic corona formed by the arms, that prevents the formation of aggregates. The lengths $L_{\mathrm{tsc}}$ of the chains of PEtOz and PiPrOz are 15.9 and $12.1 \mathrm{~nm}$ [25]. These values are almost two times higher than $L_{\mathrm{tsc}}$ for CPh6-PEtOx $\left(L_{\mathrm{tsc}}=8.5 \mathrm{~nm}\right)$ and CPh6-PiPrOx $\left(L_{\mathrm{tsc}}=6.9 \mathrm{~nm}\right)$. Accordingly, in the case of CPh6-PAlOx, the arm length is not enough for reliable screening of branching centers, and the interaction of the latter leads to the aggregate formation.

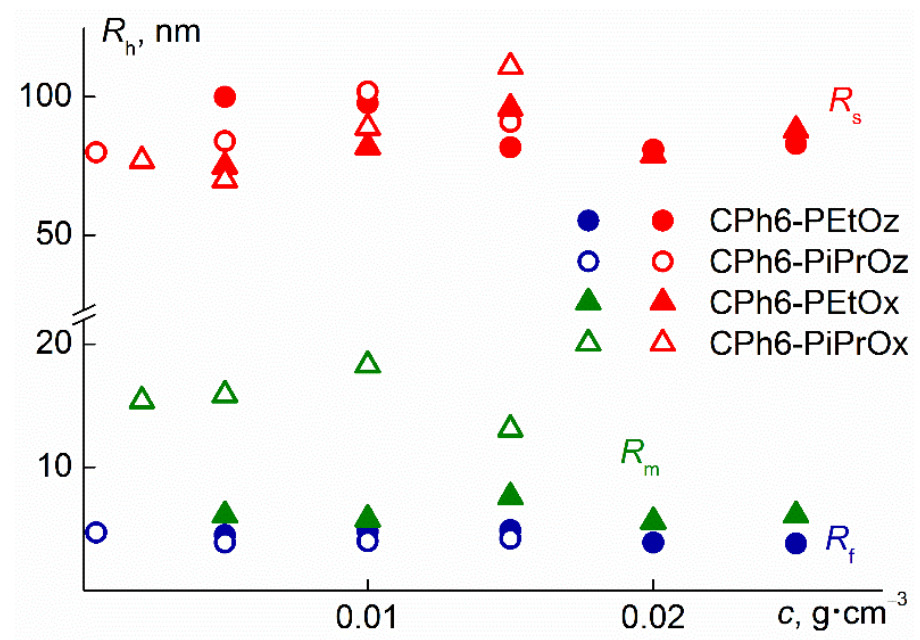

Figure 4. The dependences of the hydrodynamic radii $R_{\mathrm{h}}$ of scattering species on concentration $c$ for aqueous solutions of star-shaped CPh6-PEtOz and CPh6-PEtOx $15{ }^{\circ} \mathrm{C}$ and CPh6-PiPrOz and CPh6-PiPrOx at $21^{\circ} \mathrm{C}$.

As was shown earlier, the shape of micelle-like aggregates is close to spherical [45]. The spherical form of molecules of polymer stars with a large number of relatively short arms was proved theoretically [47] and experimentally [48]. These facts allow the estimation of the aggregation degree $m_{\mathrm{agg}}$ as the ratio of volumes of the aggregates and the macromolecules. For spherical particles, the volume is proportional to third power of their radius and for investigated $\mathrm{CPh} 6-\mathrm{PAlOx}$

$$
m_{\mathrm{agg}} \approx\left(R_{\mathrm{m}} / R_{\mathrm{h}-\mathrm{D}}\right)^{3}
$$

Thus, $m_{\text {agg }} \approx 9$ and 200 for CPh6-PEtOx and CPh6-PiPrOx, respectively. Note that such an approach is rough. First, the hydrodynamic radius is not the real dimension of dissolved species. Second, the densities of aggregates and macromolecules are different. A significant distinction in the $m_{\text {agg }}$ values for CPh6-PEtOx and CPh6-PiPrOx may be caused by the different hydrophobicity of their arms. Indeed, as shown by Winnik et al., PEtOx dehydration begins at about $50^{\circ} \mathrm{C}$, while in the case of PiPrOx, this can occur already at $20{ }^{\circ} \mathrm{C}$ [7]. Consequently, in CPh6-PiPrOx molecules at $21^{\circ} \mathrm{C}$, there can be a noticeable number of dehydrated units, the intermolecular interactions of which promote aggregation and, in particular, an increase in the size of micelle-like structures.

In addition to unimolecular micelles or small aggregates, large aggregates with a hydrodynamic radius $R_{\mathrm{s}}$ from 70 to $110 \mathrm{~nm}$ were detected in CPh6-PAlOz and CPh6-PAlOx solutions. No systematic change in $R_{\mathrm{s}}$ with concentration was found. The average values of the hydrodynamic radii $<R_{\mathrm{S}}>$ of these supramolecular structures for the studied polymers are practically the same (Table 1 ). It can be assumed that these aggregates were formed mainly by "defective" molecules, the number of arms which was less than six, and the arm length was less than the average for the sample. The relative weight concentration $c_{\mathrm{S}}$ of 
large aggregates is low. The $c_{\mathrm{S}}$ value can be roughly estimated using the models of sphere for macromolecules and micelle-like structures and coil for large aggregates. As is known, the intensity $I_{\mathrm{i}}$ of $i$ th specie is proportional to both the molar mass $M_{\mathrm{i}}$ and concentration $c$ of particles [49-51]

$$
I_{\mathrm{i}} \sim c_{\mathrm{i}} M_{\mathrm{i}}
$$

where $I_{\mathrm{i}}=S_{\mathrm{i}} I, I$ is integral light scattering intensity of solution, and $S_{\mathrm{i}}$ is relative contribution of $i$ th specie in the $I$ value. $S_{\mathrm{i}}=S_{\mathrm{f}}$ and $c_{\mathrm{i}}=c_{\mathrm{f}}$ for macromolecules, $S_{\mathrm{i}}=S_{\mathrm{m}}$ and $c_{\mathrm{i}}=c_{\mathrm{m}}$ for micelle-like structures, and $S_{\mathrm{i}}=S_{\mathrm{s}}$ for large supramolecular structures (see Figure 3 ). The particle radius $R_{\mathrm{i}}$ is related to its molar mass as $M_{\mathrm{i}} \sim R_{\mathrm{i}}^{x}$. Parameter $x$ depends on the particle shape, for example, $x=3$ for spherical particles, $x=2$ for coil structures, and $x=1$ for rigid rods. Within the described approximations, we obtain for $\mathrm{CPh} 6-\mathrm{PAlOz}$

$$
c_{\mathrm{s}} / c_{\mathrm{f}}=\left(S_{\mathrm{f}} / S_{\mathrm{s}}\right)\left(R_{\mathrm{s}}{ }^{2} / R_{\mathrm{f}}{ }^{3}\right)
$$

and CPh6-PAlOx

$$
c_{\mathrm{m}} / c_{\mathrm{f}}=\left(S_{\mathrm{m}} / S_{\mathrm{s}}\right)\left(R_{\mathrm{s}}{ }^{2} / R_{\mathrm{m}}{ }^{3}\right)
$$

The contributions $S_{\mathrm{i}}$ of different particles for solutions of investigated stars did not depend on polymer concentration. The average values of $S_{\mathrm{f}}, S_{\mathrm{m}}$, and $S_{\mathrm{s}}\left(<S_{\mathrm{f}}\right\rangle,\left\langle S_{\mathrm{m}}\right\rangle$, and $\left\langle S_{\mathrm{s}}\right\rangle$, respectively) are shown in Table 1 . Substitution of $\left\langle S_{\mathrm{f}}\right\rangle,\left\langle S_{\mathrm{m}}\right\rangle$, and $\left\langle S_{\mathrm{s}}\right\rangle$ into Equations (3) and (4) gives values of relative concentration $c_{\mathrm{S}}$ of large aggregates for each polymer studied (Table 1 ). It is clearly seen that $c_{\mathrm{s}}$ did not exceed $8 \%$.

In order to estimate the aggregation degree $m_{\text {agg }}$ for large aggregates, one can use the previously proposed approach [52] based on comparing the translational friction coefficients for macromolecules and aggregates. By modeling unimolecular micelles by spheres, and large aggregates by ellipsoids of revolution, it is possible to show that the aggregation degree associated with the parameters of the ellipsoid by the equation [52]:

$$
m_{\mathrm{agg}}=V_{\mathrm{ell}} / V_{\mathrm{sph}}=p^{2} R_{\mathrm{f}}^{3} / 8 a^{3}
$$

where $V_{\mathrm{ell}}$ is the volume of the modeling ellipsoid of revolution, $V_{\mathrm{sph}}$ is the volume of the modeling sphere, $p=a / b, a$ and $b$ are the major and minor axes of ellipsoid. Herein, the dependences of $a$ and $b$ on $p$ for a model ellipsoid of revolution with a translational friction coefficient $f$ are described by the formulas

$$
\begin{aligned}
& a=f /\left(6 \pi \eta_{0} F(p)\right) \\
& b=f /\left(6 \pi \eta_{0} p F(p)\right)
\end{aligned}
$$

where

$$
a F(p)=\left(p^{2}-1\right)^{1 / 2} /\left(p \ln \left(\left(p+\left(p^{2}-1\right)^{1 / 2}\right) /\left(p-\left(p^{2}-1\right)^{1 / 2}\right)\right)\right.
$$

For a given value of the translational friction coefficient of the ellipsoid, the $m_{\text {agg }}$ value turns out to be a rather weak function of the ellipsoid parameters. In the region of "reasonable" values of the asymmetry factor $1<p<3$, the change in $m_{\text {agg }}$ is about $30 \%$. In particular, taking into account the values of $R_{\mathrm{h}-\mathrm{D}}$ and $R_{\mathrm{S}}$ from Table 1 , at $p=2$, the values of $m_{\text {agg }}$ are from 10,000 to 20,000 for CPh6-PEtOz and CPh6-PiPrOz and from 15,000 to 25,000 for $\mathrm{CPh} 6-\mathrm{PEtOx}$ and $\mathrm{CPh} 6-\mathrm{PiPrOx}$. Therefore, for all investigated stars at low temperatures, the large aggregates contain from one to two tens of thousands of macromolecules.

Note that when estimating the relative weight concentration $c_{S}$ of large aggregates and aggregation degree $m_{\mathrm{agg}}$, we used the hydrodynamic radii of the particles and their contributions to the integral value of light scattering, which were determined using a PhotoCor Complex setup. Similar information for CPh6-PEtOz and CPh6-PEtOx solutions was obtained using a Zetasizer Nano ZS particle analyzer. Figure S1 in Supplementary Materials shows the corresponding distributions for solutions of these polymers. As might be expected, they are qualitatively similar to the dependencies shown in Figure 3. The 
average values of hydrodynamic radii $R_{\mathrm{f}}, R_{\mathrm{m}}$ and $R_{\mathrm{s}}$ obtained with different instruments coincide within the experimental error. A similar situation takes place for the contributions of particles to the integral light scattering intensity. However, one must keep in mind that the accuracy of determining these parameters is significantly lower, and the experimental error can reach $15 \%$.

\subsection{Behavior of Star-Shaped Six-Arm Pseudo-Polypeptoids in Aqueous Solutions on Heating}

A phase transition was detected in aqueous solutions of the studied polymers on heating by methods of light scattering, turbidimetry, and microcalorimetry. The temperature $T_{1}$ of the onset of phase separation was determined from the beginning of a sharp decrease in optical transmission $I^{*}$ and the beginning of a strong increase in the light scattering intensity $I$ (Figure 5 ). Below $T_{1}$, the characteristics of most of the studied solutions did not change with temperature (Figures 5 and 6). Only in some solutions with PAlOx arms, when approaching $T_{1}$, a slight increase in intensity $I$ was observed, caused by an increase in the size $R_{\mathrm{s}}$ of large aggregates and their contribution $S_{\mathrm{s}}$ to the total intensity of light scattering. This behavior distinguishes the studied polymers from the star-shaped PAlOz and PAlOx, whose cores were calix $[n]$ arenes $(n=4,8)[46,53]$. In solutions of the mentioned polymers, the processes of aggregation and self-organization at the molecular level began long before reaching $T_{1}$. Probably, this is the manifestation of the role of the branching center in the formation of the properties of thermosensitive stars in aqueous solutions.
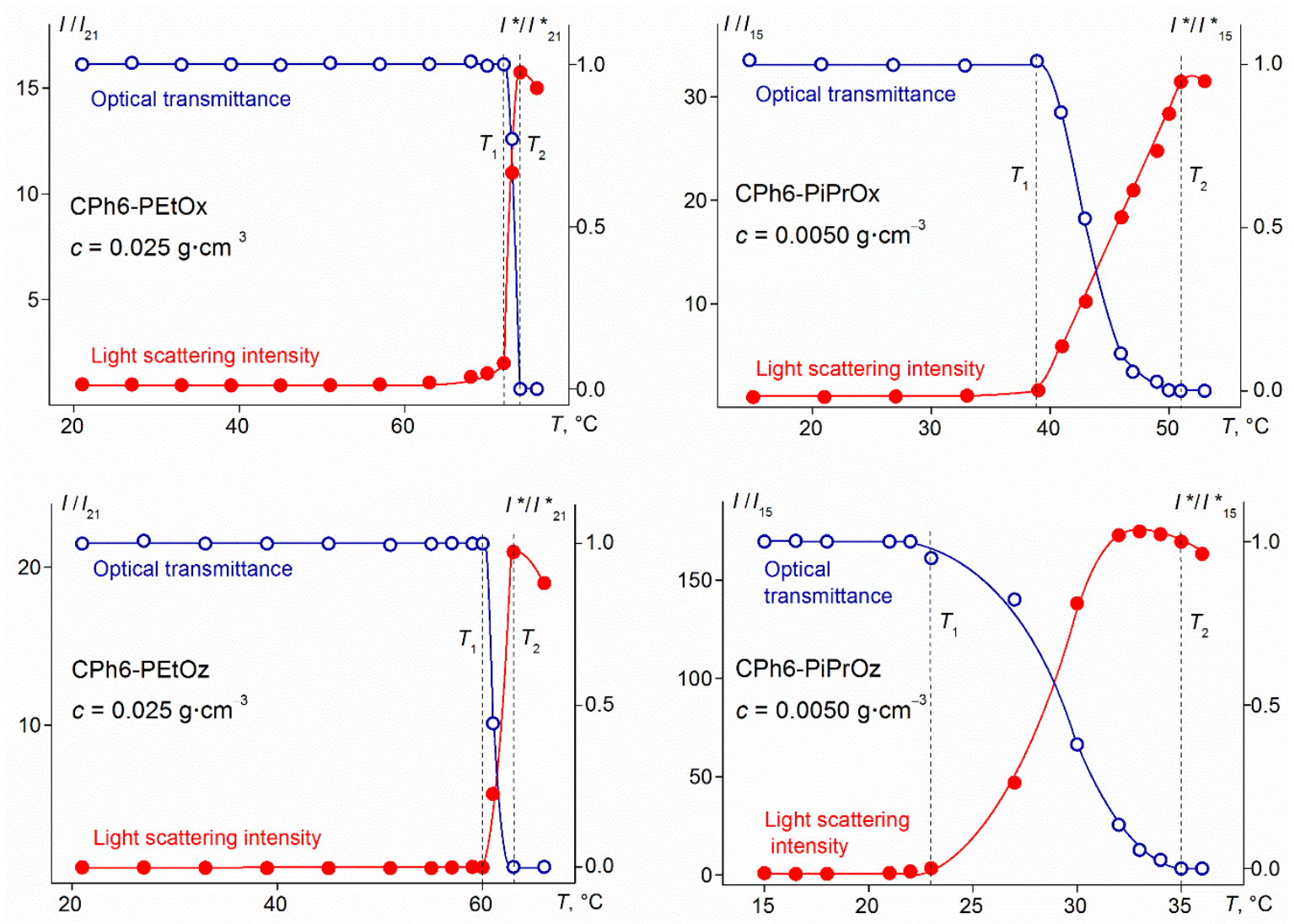

Figure 5. Temperature dependences of relative light scattering intensity $I / I_{15}$ and $I / I_{21}$ and relative transmission $I^{*} / I^{*} 15$ and $I^{*} / I^{*} 21$ for solutions of investigated star polymers. $I_{15}$ and $I_{21}$ are light scattering intensity at $15^{\circ} \mathrm{C}$ and $21^{\circ} \mathrm{C}$, respectively. $I^{*} 15$ and $I^{*}{ }_{21}$ are optical transmission at $15^{\circ} \mathrm{C}$ and $21^{\circ} \mathrm{C}$, respectively. 

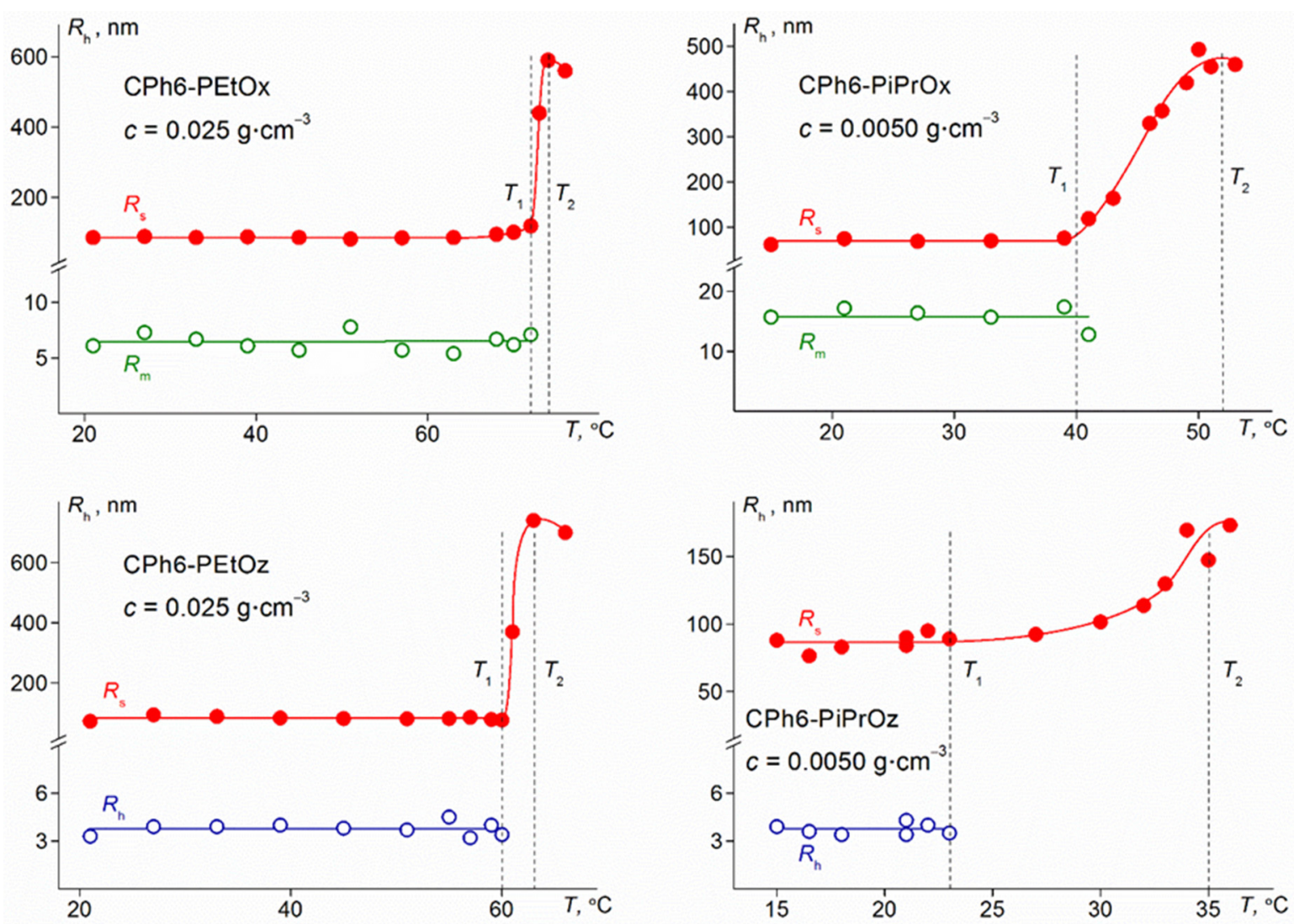

Figure 6. Temperature dependences of hydrodynamic radii $R_{\mathrm{h}}$ of scattering objects for aqueous solutions of star-shaped pseudo-polypeptoids.

Above $T_{1}$, the light scattering intensity increased very rapidly with temperature, achieving the maximum value near the temperature $T_{2}$, at which the optical transmission became zero (Figure 5). $T_{2}$ can be considered as the temperature of the finishing of the phase separation according to turbidimetry data. The reason for the observed behavior of light scattering is the growth of radius of the large aggregates (Figure 6) which is often observed for thermosensitive polymer stars $[43,46,54-56]$. At $T \geq T_{1}$, macromolecules in solutions of $\mathrm{CPh} 6-\mathrm{PAlOz}$ and small aggregates in solution of $\mathrm{CPh} 6-\mathrm{PAlOx}$ were not detected by the dynamic light scattering. Thus, at $T>T_{1}$, the dominant process in solutions of the studied star-shaped polymers was aggregation as a result of an increase in dehydration degree on heating and the formation of intermolecular hydrogen bonds. Above $T_{2}$, a decrease in the $I$ and $R_{\mathrm{S}}$ values was observed, however, a quantitative analysis of these data is impossible, since in this region the solutions are turbid and light scattering is multiple.

The microcalorimetric endotherms of the aqueous solutions of CPh6-PAlOx and $\mathrm{CPh} 6-\mathrm{PAlOz}$ are shown in Figure 7. The dependences of the phase transition heat on the concentration $\Delta H$ for the studied polymer stars had a form typical for thermosensitive polymers (Figure 8 ). Thus, no qualitative change in thermodynamic behavior was observed on passage from linear polymers to star-shaped polymers. On the other hand, the influence of the arm structure was clearly visible. As can be seen in Figure 8, for polymer stars containing isopropyl groups, the $\Delta H$ value was almost an order of magnitude higher than the phase transition heat for CPh6-PEtOz and CPh6-PEtOx, that can explain the lower hydrophobicity of the latter. It should also be noted that $\Delta H$ was slightly higher for the star-shaped CPh6-PAlOz in comparison with this characteristic for CPh6-PAlOx. 

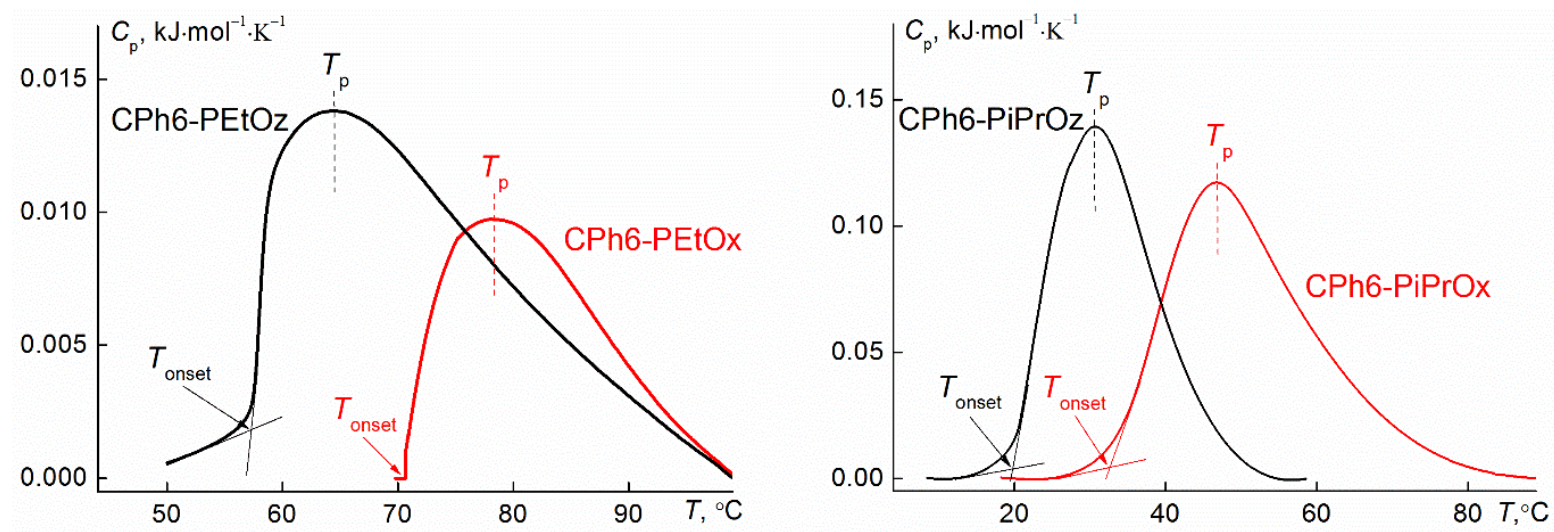

Figure 7. Microcalorimetric endotherms of CPh6-PiPrOz and CPh6-PiPrOx $\left(c=0.015 \mathrm{~g} \mathrm{~cm}^{-3}\right)$ and CPh6-PEtOz and CPh6-PEtOx $\left(c=0.025 \mathrm{~g} \mathrm{~cm}^{-3}\right)$ in water (rate $\left.1.0^{\circ} \mathrm{C} / \mathrm{min}\right)$.

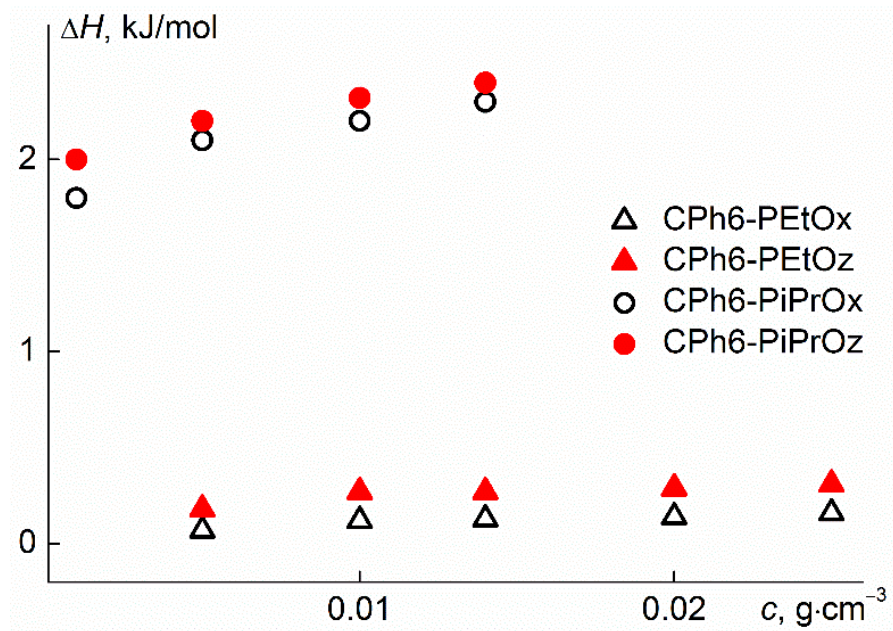

Figure 8. Concentration dependences of enthalpy for the studied aqueous solutions.

From the obtained values of $\Delta H$, the temperatures of the peak maximum and the maximum heat capacities, one can calculate the Van't Hoff enthalpy $\Delta H^{\mathrm{vH}}[57,58]$ :

$$
\Delta H^{\mathrm{vH}}=4 R T_{\mathrm{p}}^{2}\left(\mathrm{C}_{\mathrm{p}}^{\max } / \Delta H\right)
$$

where $T_{\mathrm{p}}$ is the temperature of the maximum, $C_{\mathrm{p}}$ max is the heat capacity at $T_{\mathrm{p}}$, and $R$ is universal gas constant. The ratios $n^{\prime}=\Delta H^{\mathrm{vH}} / \Delta H$ gives information about the number of structural units of the polymers that cooperate with each other in the transition [59], i.e., so-called "cooperative units". The values of $\Delta H^{\mathrm{vH}}, \Delta H$ and $n^{\prime}$ given in Table 2 were obtained for solutions with the maximum polymer concentration: $c=0.015 \mathrm{~g} \mathrm{~cm}^{-3}$ for CPh6-PiPrOz and CPh6-PiPrOx and $c=0.025 \mathrm{~g} \mathrm{~cm}^{-3}$ for CPh6-PEtOz, CPh6-PEtOx. The highest $n^{\prime}$ value was obtained for CPh6-PEtOx, which is the most hydrophilic, while for the most hydrophobic CPh6-PiPrOz, the $n^{\prime}$ parameter has the lowest value.

Table 2. Thermodynamic characteristics of solutions of star-shaped pseudo-polypeptoids.

\begin{tabular}{cccc}
\hline Polymer & $\boldsymbol{\Delta H}^{\mathbf{v H}}, \mathbf{k J} / \mathbf{m o l}$ & $\boldsymbol{\Delta} \boldsymbol{H}, \mathbf{k J} / \mathbf{m o l}$ & $\boldsymbol{n}^{\prime}$ \\
\hline CPh6-PEtOz & 6.0 & 0.3 & 20 \\
CPh6-PiPrOz & 1.8 & 2.4 & 0.75 \\
CPh6-PEtOx & 10.1 & 0.2 & 50 \\
CPh6-PiPrOx & 3.4 & 2.2 & 1.5 \\
\hline
\end{tabular}




\subsection{Concentration Dependences of Phase Separation Temperatures for Aqueous Solutions of Investigated Polymer Stars}

Figure 9 shows the concentration dependences of temperature $T_{1}$ obtained for the studied polymers. The phase separation temperatures increased with dilution. This is typical for dilute solutions of thermosensitive polymers. Table 3 compares the phase separation temperatures according to turbidimetry $\left(T_{1}\right.$ and $\left.T_{2}\right)$ and microcalorimetry $\left(T_{\text {onset }}\right.$ and $T_{p}$ ) data ( $T_{\text {onset }}$ is temperature of the onset of phase separation (see Figure 7$)$ ). For all polymers, the temperatures of the onset of phase separation, determined by discussed methods, differed insignificantly. On the other hand, the values of $T_{2}$ and $T_{\mathrm{p}}$ for stars with arms containing isopropyl groups differed by $8{ }^{\circ} \mathrm{C}$. The observed distinctions can be associated with both different physical bases of the methods and with different experimental procedures (discrete temperature variation and constant heating).

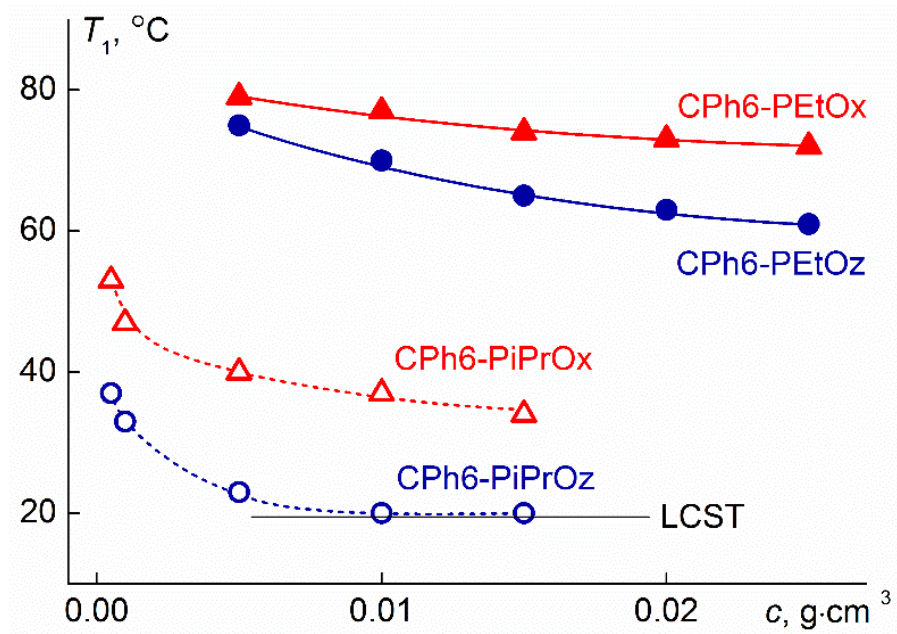

Figure 9. Concentration dependencies of the phase separation temperature $T_{1}$ for star-shaped CPh6-PAlOz and CPh6-PAlOx.

Table 3. Phase separation temperatures of solutions of star-shaped pseudo-polypeptoids at concentration $c=0.015 \mathrm{~g} \mathrm{~cm}^{-3}$.

\begin{tabular}{crccc}
\hline Sample & $\boldsymbol{T}_{\text {onset }}{ }^{\circ} \mathbf{C}$ & $\boldsymbol{T}_{\mathbf{p}},{ }^{\circ} \mathbf{C}$ & $\boldsymbol{T}_{\mathbf{1}},{ }^{\circ} \mathbf{C}$ & $\boldsymbol{T}_{\mathbf{2}},{ }^{\circ} \mathbf{C}$ \\
\hline CPh6-PEtOz & 63 & 70 & 65 & 70 \\
CPh6-PiPrOz & 20 & 31 & 20 & 23 \\
CPh6-PEtOx & 75 & 83 & 74 & - \\
CPh6-PiPrOx & 33 & 47 & 34 & 39 \\
\hline
\end{tabular}

The lower critical solution temperature (LCST) was determined only for CPh6-PiPrOz. Taking into account the character of the dependences of $T_{1}$ on $c$, it can be assumed that for other samples LCST slightly differs from the $T_{1}$ value obtained at the maximum studied concentration. As for the absolute values of the phase transition temperatures, for stars with oxazoline arms, they do not differ very much from the cloud points for linear $[6,20,33,60]$ and star-shaped $[26,27,33,53,61]$ PEtOx and PiPrOx. For PAlOz, the data are much less even for linear polymers [20,24], and for star-shaped CPh6-PAlOz they are absent at all. Besides, when analyzing the phase separation temperatures, it is necessary to take into account the influence of at least the molar mass of the polymer and the hydrophilic-hydrophobic balance [33], and it is rather difficult to draw reliable conclusions about the "chemical structure-macromolecule architecture-phase separation temperature" correlations.

As expected, for stars with more hydrophilic arms CPh6-PEtOz and CPh6-PEtOx, higher phase separation temperatures were obtained in comparison with $T_{1}$ for the $\mathrm{CPh} 6$ $\mathrm{PiPrOz}$ and CPh6-PiPrOx solutions. This difference is quite large, at a given concentration it is $40-45{ }^{\circ} \mathrm{C}$ and correlates with the data for linear PEtOx and PiPrOx [20,33,60]. At passage 
from PAlOx to PAlOz, the hydrophobicity of the polymer increases as a result of the elongation of the monomer unit by one $-\mathrm{CH}_{2}-$ group. This leads to a decrease in the phase separation temperature. In the investigated concentration range, in the pair of $\mathrm{CPh} 6-\mathrm{PEtOz}$ and CPh6-PEtOx, the $T_{1}$ values differ by $5-10^{\circ} \mathrm{C}$, and for $\mathrm{CPh} 6-\mathrm{PiPrOz}$ and $\mathrm{CPh} 6-\mathrm{PiPrOx}$ the distinction is more (from 14 to $17^{\circ} \mathrm{C}$ ). It should be borne in mind that $\mathrm{CPh} 6-\mathrm{PEtOz}$ and $\mathrm{CPh} 6-\mathrm{PiPrOz}$ are characterized by higher molar mass. This should have led to a decrease in the phase separation temperatures for stars with $\mathrm{PAlOz}$ arms. Therefore, the discussed difference in the $T_{1}$ values for CPh6-PAlOz and CPh6-PAlOx could be slightly smaller if the compared samples had similar molar masses and hydrophilic-hydrophobic balance.

Note that the values of the phase separation temperatures and LCST can be significantly influenced by the polydispersion of the samples [62]. Therefore, the dispersion should be taken into account when analyzing the $T_{1}$ values. However, as can be seen from Table 1, the values of $Ð$ for the studied CPh6-PAlOz and CPh6-PAlOx are close. Accordingly, it can be assumed that the effect of polydispersion will be minimal.

The effect of the structure of the studied stars is most pronounced when comparing CPh6-PEtOz and CPh6-PiPrOx. The monomer units of the arms of these polymers have the same set of atoms and groups, but for $\mathrm{CPh} 6-\mathrm{PEtOz}$ the phase separation temperatures are about $40{ }^{\circ} \mathrm{C}$ higher than $T_{1}$ for CPh6-PiPrOx. Consequently, the position of the $-\mathrm{CH}_{2}-$ group, namely in the main chain or in the side fragments, is a decisive factor determining the phase separation temperature. Note also that the difference in the $T_{1}$ values for CPh6-PEtOz and CPh6-PEtOx is significantly less than the corresponding difference for CPh6-PiPrOz and CPh6-PiPrOx, i.e., the higher the hydrophobicity of the homologues, the greater the difference in the phase separation temperatures of their solutions.

\section{Conclusions}

Aqueous solutions of star-shaped six-arm pseudo-polypeptoids on heating were investigated within a wide concentration and temperature ranges. Poly-2-ethyl-2-oxazine, poly-2-isopropyl-2-oxazine, poly-2-ethyl-2-oxazoline, and poly-2-isopropyl-2-oxazoline were arms and hexaaza $\left[2_{6}\right]$ orthoparacyclophane was core.

At low temperatures, the behavior of the solutions depended on the structure and size of arms. Macromolecules, more precisely unimolecular micelles, and large aggregates were observed in solutions of poly-2-alkyl-2-oxazines, while in solutions of poly-2-alkyl2-oxazolines there were two types of aggregates. The formation of the smaller ones is caused by interaction of hydrophobic CPh6 core, because the short arms do not sufficiently shield them from the solvent. In addition to unimolecular micelles and small aggregates, in aqueous solutions of the studied polymer stars, large loose aggregates were present, which contained from 10,000 to 25,000 macromolecules. These supramolecular structures were formed mainly from molecules, the arm number in which was less than six, and the arm length was less than the average for the sample. The weight fraction of large aggregates did not exceed $8 \%$.

On heating below the phase separation temperature, in contrast to the previously studied pseudo-polypeptoids with a calix[n]arene core, the characteristics of the CPh6$\mathrm{PAlOz}$ and $\mathrm{CPh} 6-\mathrm{PAlOx}$ solutions were practically independent of temperature. This behavior can be explained by the influence of the structure of the branching center. Within the phase separation interval, the prevailing process was aggregation due to the formation of intermolecular hydrogen bonds. This led to the fact that unimolecular micelles and small aggregates attached to large aggregates or formed new supramolecular structures, the size of which increased on heating.

For all investigated solutions, the phase separation temperatures increased with dilution, but LCST was determined reliably only for star with poly-2-isopropyl-2-oxazine arms. At a given concentration, the phase separation temperatures for poly-2-alkyl-2oxazoline stars with $\mathrm{CPh} 6$ core differed from their values for linear analogs and stars with branch centers of a another structure. These differences are insignificant and can be caused both by the difference in the structure and architecture of the molecules of the compared 
samples, and by the influence of the molar mass of the polymers. It was shown that an increase in the arm hydrophobicity leads to a decrease in the phase separation temperature of the aqueous solutions of studied stars. In particular, their values for poly-2-alkyl-2oxazolines are higher than for poly-2-alkyl-2-oxazines. On passage from CPh6-PEtOz to CPh6-PiPrOz and from CPh6-PEtOx to CPh6-PiPrOx, the phase separation temperatures decreased. Besides, for polymer stars containing isopropyl groups, the phase transition heat was almost an order of magnitude higher than the $\Delta H$ value for star with ethyl groups in side fragment of arms.

Supplementary Materials: The following are available online at https:/ / www.mdpi.com/article/10 .3390/polym13091429/s1, Figure S1: The distributions of scattering species over hydrodynamic radii for solutions of star-shaped CPh6-PEtOx and CPh6-PEtOz. Rf, Rm, and Rs, are the hydrodynamic radii of macromolecules (fast mode), small aggregates (middle mode) and large aggregates (slow mode), respectively.

Author Contributions: Conceptualization, A.F.; methodology, H.T.; writing-original draft preparation, A.T., A.F. and T.K.; formal analysis V.A., A.T., and T.K.; investigation, T.K., and A.S.; resources V.A., and A.S.; data curation, A.S.; writing—review and editing, A.S. and V.A.; visualization, T.K.; supervision, A.F.; project administration, A.F. and H.T.; funding acquisition, T.K. All authors have read and agreed to the published version of the manuscript.

Funding: This research was funded by the Russian Science Foundation, grant number 19-73-00175.

Institutional Review Board Statement: Not applicable.

Informed Consent Statement: Not applicable.

Data Availability Statement: Not applicable.

Acknowledgments: Authors acknowledge the support for microcalorimetric studies EC H2020MSCA-RISE-2018/823883: Soft Biocompatible Polymeric NANOstructures: A Toolbox for Novel Generation of Nano Pharmaceuticals in Ophthalmology (NanoPol).

Conflicts of Interest: The authors declare no conflict of interest.

\section{References}

1. Glassner, M.; Vergaelen, M.; Hoogenboom, R. Poly(2-oxazoline)s: A comprehensive overview of polymer structures and their physical properties. Polym. Int. 2017, 67, 32-45. [CrossRef]

2. Wu, W.; Wang, W.; Li, J. Star polymers: Advances in biomedical applications. Prog. Polym. Sci. 2015, 46, 55-85. [CrossRef]

3. Zahoranova, A.; Luxenhofer, R. Poly(2-oxazoline)- and poly(2-oxazine)-based self-assemblies, polyplexes, and drug nanoformulations-An update. Adv. Healthcare Mater. 2021, 10, 2001382. [CrossRef] [PubMed]

4. Pei, Y.; Jarrett, K.; Saunders, M.; Roth, P.J.; Buckley, C.E.; Lowe, A.B. Triply responsive soft matter nanoparticles based on poly[oligo(ethylene glycol) methyl ether methacrylate-block-3-phenylpropyl methacrylate] copolymers. Polym. Chem. 2016, 7, 2740-2750. [CrossRef]

5. Verbraeken, B.; Monnery, B.D.; Lava, K.; Hoogenboom, R. The chemistry of poly(2-oxazoline)s. Eur. Polym. J. 2017, 88, 451-469. [CrossRef]

6. Weber, C.; Hoogenboom, R.; Schubert, U.S. Temperature responsive bio-compatible polymers based on poly(ethylene oxide) and poly(2-oxazoline)s. Prog. Polym. Sci. 2012, 37, 686-714. [CrossRef]

7. Takahashi, R.; Sato, T.; Terao, K.; Qiu, X.-P.; Winnik, F.M. Self-association of a thermosensitive poly(alkyl-2-oxazoline) block copolymer in aqueous solution. Macromolecules 2012, 45, 6111-6119. [CrossRef]

8. Caponi, P.F.; Qiu, X.P.; Vilela, F.; Winnik, F.M.; Ulijn, R.V. Phosphatase/temperature responsive poly(2-isopropyl-2-oxazoline). Polym. Chem. 2011, 2, 306-308. [CrossRef]

9. Vlassi, E.; Papagiannopoulos, A.; Pispas, S. Amphiphilic poly(2-oxazoline) copolymers as self-assembled carriers for drug delivery applications. Eur. Polym. J. 2017, 88, 516-523. [CrossRef]

10. Zhang, N.; Luxenhofer, R.; Jordan, R. Thermoresponsive poly(2-oxazoline) molecular brushes by living ionic polymerization: Modulation of the cloud point by random and block copolymer pendant chains. Macromol. Chem. Phys. 2012, 213, 1963-1969. [CrossRef]

11. Amirova, A.I.; Blokhin, A.N.; Razina, A.B.; Tenkovtsev, A.V.; Filippov, A.P. The behavior of thermoresponsive star-shaped poly-2-isopropyl-2-oxazoline in saline media. Mendeleev Commun. 2019, 29, 472-474. [CrossRef]

12. Luxenhofer, R.; Han, Y.; Schulz, A.; Tong, J.; He, Z.; Kabanov, A.V.; Jordan, R. Poly(2-oxazoline)s as polymer therapeutics. Macromol. Rapid Commun. 2012, 33, 1613-1631. [CrossRef] [PubMed] 
13. De la Rosa, V.R. Poly(2-oxazoline)s as materials for biomedical applications. J. Mater. Sci. Mater. 2013, 25, 1211-1225. [CrossRef]

14. Drakalska, E.; Momekova, D.; Manolova, Y.; Budurova, D.; Momekov, G.; Genova, M.; Antonov, L.; Lambov, N.; Rangelov, S. Hybrid liposomal PEGylated calix[4]arene systems as drug delivery platforms for curcumin. Int. J. Pharm. 2014, 472, 165-174. [CrossRef]

15. Morgese, G.; Verbraeken, B.; Ramakrishna, S.N.; Gombert, Y.; Cavalli, E.; Rosenboom, J.G.; Zenobi-Wong, M.; Spencer, N.D.; Hoogenboom, R. Chemical design of non-ionic polymer brushes as biointerfaces: Poly(2-oxazine)s outperform both poly(2oxazoline)s and PEG. Angew. Chem. Int. Ed. 2018, 57, 11667-11672. [CrossRef] [PubMed]

16. Bloksma, M.M.; Schubert, U.S.; Hoogenboom, R. Poly(cyclic imino ether)s beyond 2-substituted-2-oxazolines. Macromol. Rapid Commun. 2011, 32, 1419-1441. [CrossRef]

17. Sinnwell, S.; Ritter, H. Microwave accelerated polymerization of 2-phenyl-5,6-dihydro-4H-1,3-oxazine: Kinetics and influence of end-groups on glass transition temperature. Macromol. Rapid Commun. 2006, 27, 1335-1340. [CrossRef]

18. Terashima, T.; Kojima, H.; Sawamoto, M. Core-imprinted star polymers via living radical polymerization: Precision cavity microgels for selective molecular recognition. Chem. Lett. 2014, 43, 1690-1692. [CrossRef]

19. Kobayashi, S.; Igarashi, T.; Moriuchi, Y.; Saegusa, T. Block copolymers from cyclic imino ethers: A new class of nonionic polymer surfactant. Macromolecules 1986, 19, 535-541. [CrossRef]

20. Bloksma, M.M.; Paulus, R.M.; van Kuringen, H.P.C.; van der Woerdt, F.; Lambermont-Thijs, H.M.L.; Schubert, U.S.; Hoogenboom, R. Thermoresponsive poly(2-oxazine)s. Macromol. Rapid Commun. 2011, 33, 92-96. [CrossRef]

21. Lambermont-Thijs, H.M.L.; Fijten, M.W.M.; van der Linden, A.J.; van Lankvelt, B.M.; Bloksma, M.M.; Schubert, U.S.; Hoogenboom, R. Efficient cationic ring-opening polymerization of diverse cyclic imino ethers: Unexpected copolymerization behavior. Macromolecules 2011, 44, 4320-4325. [CrossRef]

22. Meyer, M.; Antonietti, M.; Schlaad, H. Unexpected thermal characteristics of aqueous solutions of poly(2-isopropyl-2-oxazoline). Soft Matter 2007, 3, 430-431. [CrossRef] [PubMed]

23. Demirel, A.L.; Meyer, M.; Schlaad, H. Formation of polyamide nanofibers by directional crystallization in aqueous solution. Angew. Chem. Int. Ed. 2007, 46, 8622-8778. [CrossRef] [PubMed]

24. Lübtow, M.M.; Hahn, L.; Haider, M.S.; Luxenhofer, R. Drug specificity, synergy and antagonism in ultrahigh capacity poly(2oxazoline)/poly(2-oxazine) based formulations. J. Am. Chem. Soc. 2017, 139, 10980-10983. [CrossRef] [PubMed]

25. Kirila, T.; Smirnova, A.; Razina, A.; Tenkovtsev, A.; Filippov, A. Synthesis and conformational characteristics of thermosensitive star-shaped six-arm polypeptoids. Polymers 2020, 12, 800. [CrossRef]

26. Sezonenko, T.; Qiu, X.P.; Winnik, F.M.; Sato, T. Dehydration, micellization, and phase separation of thermosensitive polyoxazoline star block copolymers in aqueous solution. Macromolecules 2019, 52, 935-944. [CrossRef]

27. Kowalczuk, A.; Kronek, J.; Bosowska, K.; Trzebicka, B.; Dworak, A. Star poly(2-ethyl-2-oxazoline)s-synthesis and thermosensitivity. Polym. Int. 2011, 60, 1001-1009. [CrossRef]

28. Angot, S.; Murthy, K.S.; Taton, D.; Gnanou, Y. Scope of the copper halide/bipyridyl system associated with calixarene-based multihalides for the synthesis of well-defined polystyrene and poly(meth)acrylate stars. Macromolecules 2000, 33, 7261-7274. [CrossRef]

29. Strandman, S.; Hietala, S.; Aseyev, V.; Koli, B.; Butcher, S.J.; Tenhu, H. Supramolecular assemblies of amphiphilic PMMA-blockPAA stars in aqueous solutions. Polymer 2006, 47, 6524-6535. [CrossRef]

30. Smith, G.W. Crystal Structure of a Nitrogen Isostere of Pentacyclo-Octacosadodecaene. Nature 1963, 198, 879. [CrossRef]

31. Gawroński, J.; Kołbon, H.; Kwit, M.; Katrusiak, A. Designing large triangular chiral macrocycles: Efficient [3 + 3] diamine-dialdehyde condensations based on conformational bias. J. Org. Chem. 2000, 65, 5768-5773. [CrossRef] [PubMed]

32. Kirila, T.; Smirnova, A.; Razina, A.; Tenkovtsev, A.; Filippov, A. Influence of salt on the self-organization in solutions of star-shaped poly-2-alkyl-2-oxazoline and poly-2-alkyl-2-oxazine on heating. Polymers 2021, 13, 1152. [CrossRef]

33. Amirova, A.; Rodchenko, S.; Milenin, S.; Tatarinova, E.; Kurlykin, M.; Tenkovtsev, A.; Filippov, A. Influence of a hydrophobic core on thermoresponsive behavior of dendrimer-based star-shaped poly(2-isopropyl-2-oxazoline) in aqueous solutions. J. Polym. Res. 2017, 24, 124. [CrossRef]

34. Salzinger, S.; Huber, S.; Jaksch, S.; Busch, P.; Jordan, R.; Papadakis, C.M. Aggregation behavior of thermo-responsive poly(2oxazoline)s at the cloud point investigated by FCS and SANS. Colloid. Polym. Sci. 2012, 290, 385-400. [CrossRef]

35. Krumm, C.; Fik, C.P.; Meuris, M.; Dropalla, G.J.; Geltenpoth, H.; Sickmann, A.; Tiller, J.C. Well-defined amphiphilic poly(2oxazoline) ABA-triblock copolymers and their aggregation behavior in aqueous solution. Macromol. Rapid Commun. 2012, 33, 1677-1682. [CrossRef] [PubMed]

36. Xu, J.; Luo, S.; Shi, W.; Liu, S. Two-stage collapse of unimolecular micelles with double thermoresponsive coronas. Langmuir 2006, 22, 989-997. [CrossRef]

37. Kyriakos, K.; Aravopoulou, D.; Augsbach, L.; Sapper, J.; Ottinger, S.; Psylla, C.; Aghebat Rafat, A.; Benitez-Montoya, C.A.; Miasnikova, A.; Di, Z.; et al. Novel thermoresponsive block copolymers having different architectures—Structural, rheological, thermal, and dielectric investigations. Colloid. Polym. Sci. 2014, 292, 1757-1774. [CrossRef]

38. Witte, H.; Seeliger, W. Cyclische imidsäureester aus nitrilen und aminoalkoholen. Lieb. Ann. 1974, 6, 996-1009. [CrossRef]

39. Trinh, L.T.T.; Lambermont-Thijs, H.M.L.; Schubert, U.S.; Hoogenboom, R.; Kjoniksen, A.L. Thermoresponsive poly(2-oxazoline) block copolymers exhibiting two cloud points: Complex multistep assembly behavior. Macromolecules 2012, 45, 4337-4345. [CrossRef] 
40. Steinschulte, A.A.; Schulte, B.; Rutten, S.; Eckert, T.; Okuda, J.; Moller, M.; Schneider, S.; Borisov, O.V.; Plamper, F.A. Effects of architecture on the stability of thermosensitive unimolecular micelles. Phys. Chem. Chem. Phys. 2014, 16, 4917-4932. [CrossRef] [PubMed]

41. Dimitrov, I.; Trzebicka, B.; Müller, A.H.E.; Dworak, A.; Tsvetanov, C.B. Thermosensitive water-soluble copolymers with doubly responsive reversibly interacting entities. Prog. Polym. Sci. 2007, 32, 1275-1343. [CrossRef]

42. Rossegger, E.; Schenk, V.; Wiesbrock, F. Design strategies for functionalized poly(2-oxazoline)s and derived materials. Polymers 2013, 5, 956-1011. [CrossRef]

43. Amirova, A.; Golub, O.; Kirila, T.; Razina, A.; Tenkovtsev, A.; Filippov, A. Influence of arm length on aqueous solution behavior of thermosensitive poly(2-isopropyl-2-oxazoline) stars. Colloid Polym. Sci. 2017, 295, 117-124. [CrossRef]

44. Kirila, T.; Smirnova, A.; Kurlykin, M.; Tenkovtsev, A.; Filippov, A. Self-organization in aqueous solutions of thermosensitive star-shaped and linear gradient copolymers of 2-ethyl-2-oxazoline and 2-isopropyl-2-oxazoline. Colloid Polym. Sci. 2020, 298, 535-546. [CrossRef]

45. Smirnova, A.V.; Kirila, T.U.; Kurlykin, M.P.; Tenkovtsev, A.V.; Filippov, A.P. Behavior of aqueous solutions of polymer star with block copolymer poly(2-ethyl-2-oxazoline) and poly(2-isopropyl- 2-oxazoline) arms. Int. J. Polym. Anal. Charact. 2017, 22, 677-684. [CrossRef]

46. Kirila, T.U.; Smirnova, A.V.; Filippov, A.S.; Razina, A.B.; Tenkovtsev, A.V.; Filippov, A.P. Thermosensitive star-shaped poly-2ethyl-2-oxazine. Synthesis, structure characterization, conformation, and self-organization in aqueous solutions. Eur. Polym. J. 2019, 120, 109215. [CrossRef]

47. Daoud, M.; Cotton, J.P. Star shaped polymers: A model for the conformation and its concentration dependence. J. Phys. 1982, 43, 531-538. [CrossRef]

48. Simonova, M.A.; Tarasova, E.V.; Dudkina, M.M.; Tenkovtsev, A.V.; Filippov, A.P. Synthesis and hydrodynamic and conformation properties of star-shaped polystyrene with calix [8] arene core. Int. J. Polym. Anal. Charact. 2019, 24, 87-95. [CrossRef]

49. Kratochvil, P. Classical Light Scattering from Polymer Solution, 1st ed.; Elsevier: Amsterdam, The Netherlands, 1987.

50. Schärtl, W. Light Scattering from Polymer Solutions and Nanoparticle Dispersions, 1st ed.; Springer: Berlin, Germany, 2007.

51. Øgendal, L.H. Light Scattering Demystified Theory and Practice; University of Copenhagen: Copenhagen, Danmark, 2017.

52. Rodchenko, S.; Amirova, A.; Kurlykin, M.; Tenkovtsev, A.; Milenin, S.; Filippov, A. Amphiphilic molecular brushes with regular polydimethylsiloxane backbone and poly-2-isopropyl-2-oxazoline side chains. 2. Self-organization in aqueous solutions on heating. Polymers 2021, 13, 31. [CrossRef] [PubMed]

53. Kirile, T.Y.; Tobolina, A.I.; Elkina, A.A.; Kurlykin, M.P.; Ten'kovtsev, A.V.; Filippov, A.P. Self-assembly processes in aqueous solutions of heat-sensitive star-shaped poly-2-ethyl-2-oxazoline. Fibre Chem. 2018, 50, 248-251. [CrossRef]

54. Kowalczuk, A.; Mendrek, B.; Żymełka-Miara, I.; Libera, M.; Marcinkowski, A.; Trzebicka, B.; Smet, M.; Dworak, A. Solution behavior of star polymers with oligo(ethylene glycol) methyl ether methacrylate arms. Polymer 2012, 53, 5619-5631. [CrossRef]

55. Qiu, F.; Wang, D.; Wang, R.; Huan, X.; Tong, G.; Zhu, Q.; Yan, D.; Zhu, X. Temperature-induced emission enhancement of star conjugated copolymers with poly(2-(dimethylamino) ethyl methacrylate) coronas for detection of bacteria. Biomacromolecules 2013, 14, 1678-1686. [CrossRef] [PubMed]

56. Le Dévédec, F.; Strandman, S.; Baille, W.E.; Zhu, X.X. Functional star block copolymers with a cholane core: Thermoresponsiveness and aggregation behavior. Polymer 2013, 54, 3898-3903. [CrossRef]

57. Privalov, P.L. Physical basis of the stability of the folded conformations of proteins. In Protein Folding; Creighton, T.E., Ed.; W.H. Freeman and Co.: New York, NY, USA, 1992; pp. 83-126.

58. Tiktopulo, E.I.; Bychkova, V.E.; Ricka, J.; Ptitsyn, O.B. Cooperativity of the coil-globule transition in a homopolymer: Microcalorimetric study of Poly(N-sopropylacrylamide). Macromolecules 1994, 27, 2879-2882. [CrossRef]

59. Ladbury, J.E.; Chowdhry, B.Z. Biocalorimetry: Applications of Calorimetry in the Biological Sciences; John Wiley and Sons: Chichester, UK, 1998.

60. Hoogenboom, R.; Schlaad, H. Thermoresponsive poly(2-oxazoline)s, polypeptoids, and polypeptides. Polym. Chem. 2017, 8, 24-40. [CrossRef]

61. Rodchenko, S.; Amirova, A.; Milenin, S.; Kurlykin, M.; Tenkovtsev, A.; Filippov, A. Self-organization of thermosensitive starshaped poly(2-isopropyl-2-oxazolines) influenced by arm number and generation of carbosilane dendrimer core in aqueous solutions. Colloid Polym. Sci. 2020, 298, 355-363. [CrossRef]

62. Atanase, L.I.; Riess, G. Thermal cloud point fractionation of poly(vinyl alcohol-co-vinyl acetate): Partition of nanogels in the fractions. Polymers 2011, 3, 1065-1075. [CrossRef] 